Фейзер (phaser) - дуже тонкий і підступний ефект. Так, будучи використаний на концертах Greatful Dead, натовп уявляла, що він виходить зсередини їх мозку [2, с.78]. Фленжер і фейзер досить складно поєднуються зі флейтою, але вони $є$ незамінні коли треба отримати певне психоделічне звучання.

Також існують способи застосування ефектів у реальному часі, наприклад, на концерті, користуючись спеціальним обладнанням. Використовуючи ефекти та способи обробки звуку можливо досягти нового звучання флейти, або переосмислити та покращити класичне.

\title{
Література:
}

1. Все про професійний звук [Електронний ресурс] // All Pro Sound. 2015. - Режим доступу до ресурсу: http://www.allprosound.ru/about/

2. Гібсон Д. ; під. ред. Петерсона Г. «Мистецтво зведення». Візуальне керівництво зі звукозапису і продюсування / Д. Гібсон., 2007.

3. Ракунова I. Н. Нові композиторські технології. Творчість Алли Загайкевич. / І. Н. Ракунова. - Київ: Фенікс, 2010.

DOI https://doi.org/10.30525/978-9934-26-004-9-85

\section{ЗНАК І СИМВОЛ - ПІКТОГРАМИ КРІЗЬ СТОЛІТТЯ: СОЦІОКУЛЬТУРНЕ ТА ПРИКЛАДНЕ ЗНАЧЕННЯ}

\author{
Дядюх-Богатько Н. Й. \\ кандидат мистецтвознавства, доиент, \\ завідувач кафедри \\ Української академії друкарства \\ м. Львів, Украӥна
}

Графічні символи крізь тисячоліття виринають від наших прапрадідів на стінах печер, кам'яних стелах по степах, керамічних рештках археологічних культур, як написи-орнаменти на зброї, архітектурних вцілілих рештках та на пізніших носіях історичної пам'яті - папері. Видряпані гострими предметами чи намальовані вохрою давні графічні символи могли містить солярні, зооморфні, антропоморфні зображення, поєднання яких розгадують наші вчені. Хоч для сучасників ці графеми несли цілком реальний комунікативний посил.

Перехід поодиноких символічних знаків до низки їх поєднань вважають наступним кроком для низки гіпотез. Це ще можна прирівняти 68 
до так званого ідеографічного письма, коли знаки передають символіку ідей. Ці давні архаїчні традиції збережені в окремих регіонах до XX ст., в орнаментиці українських гравірованих, різьблених, вишитих, мальованих народних ужиткових творах (писанок, вишиванок та ін.). Сплески модних тенденцій в Україні загострили популярність орнаментованих побутових речей, зокрема на сучасному одязі, в металевих прикрасах. Художники i дизайнери запозичують давні мотиви для декорування сучасних фасонів, проте часто ставляться до давніх графічних схем як до декоративного елементу і інтуїтивно використовують їх.

Давні графічні поєднання малюнків, зображень, подій спрощеними схемами чи знаками прийнято в науковому світі називати піктографічним письмом. Саме піктограми дозволяли спілкування поза межами володіння одним діалектом чи мовою, і часто $є$ зрозумілими і в інший час.

На основі грунтовно дослідження давніх архаїчних металевих предметів в Західній Україні, нами було підсумована ряд фактів: декор у XVIII-XIX ст. поділявся на вільний та такий, композиція якого підпорядковувалась формі; народні майстри, обираючи для декорування конструктивно складні предмети частіше використовували прості орнаментальні мотиви; на центральних частинах композиційних полів використовували солярні розети, дерево-вазони, хрестоподібні мотиви, що приховували глибокий сакральний зміст [1, с. 117].

Та у своїй монографії висуваємо гіпотезу, що поєднання солярного знака із зубчастими рядами довкола, це стилізовані зображення людей в замкнутому орнаментальному полі символізує колективну працю на конкретній території у певний час, який міг би вимірюватись за рухом сонця [тут же, с. 96]

Ми погоджуємось $з$ припущеннями О. Никорак, що «стародавні узори є своєрідним літописом глибоких шарів народної культури, в яких відображені відповідні етапи розвитку суспільства. Окремі елементи орнаментів, очевидно, беруть свій початок 3 первісного мистецтва, ще коли були знаками-оберегами. Згодом ці стилізовані мовити збереглися як декоративні елементи» [2, с. 70].

Різниця між орнаментом та піктографічним письмом полягає у спрощеності зображень, стертому культурному контексті історичної пам'яті та внаслідок цього забутті і втраті їх смислу та сенсу.

Коли на одному предметі, фрагменті розміщені поруч кільканадцять знаків, ми вже починаємо говорити про письмо. До одного 3 найдавніших видів письма на території Свропи відносять рунічне письмо. Причому на давніх кам'яних зразках поруч знаходимо зображення людської голови, звіра у центрі і рунічними підписами довкола [3, с. 76]. Відголоски рунічного письма знаходять і на території 
України. Так поблизу міста Ковель (Волинська обл.) було знайдено наконечник списа напис 3 рунічним письмом. Спроби розшифрувати зміст написів більш детально досліджує Левус П.М. [4].

Краще збереженими до сьогодні знання про витоки латинки. 3 огляду на це цікавим $\epsilon$ фрагмент давньо-римської черепиці, знайдений на території Віндобони - кельтського поселення, попередника сучасного Відня (Австрія). Містить напис латиною: «venturam terris, vides me», що дослівно перекладається так: «якщо ти мене бачиш, я впала на землю» [5]. Що демонструє нам не лише символічність графічних знаків, а вже складове письмо з гумористичним настроєм.

Фокусом нашого дослідження $є$ письмо яке знову трансформуються у піктограми. Піктограми активно увійшли в наше життя 3 початком XXI ст. Вони є невід'ємним елементом неформального електронного спілкування. Що стало причиною їх шаленої популярності? На нашу думку глобалізація соціокультурного контексту потребувала все більш універсального засобу для спілкування і на допомогу прийшли давно забуті форми: піктограми.

Чи впливає національне походження людини на особливості трактування того чи іншого знака. Соціокультурний контекст був тисячоліттями базовим у цьому понятті. Питання різниці сприйняття знака добре розроблене в лінгвістиці. В вперше Україні звернув увагу на співвідношення образу і слова Потебня О. [6]. В Європі тема образу, знака i слова грунтовно розроблена. До XX ст. у світовому мистецтвознавстві користувались методикою, розробленою Е. Панофським відомою як іконографічний аналіз.

На початку XX ст. двоє вчених Ф. Соссюр та Ч. Пірс розробили теорію знаків. За Соссюром, знак складається з двох частин: «того, що означує» - форми, яку приймає знак та «означуваного» - поняття, яке він репрезентує. Відносини між ними і $є$ процесом означення. Соссюр звернув увагу на те, що для розуміння значення творів мистецтва важливо розглядати не тільки, як художник це бачив, але і як глядач, $\mathrm{i}$ культура сприймають створення цих значень [7].

Пірс пояснив структуру символів інакше, у нього знак складається вже $з$ трьох частин: «презентація» - форма, яку приймає символ (не обов'язковий елемент), «інтерпретатор» - сенс знака та «об'єкт»- річ, до якої знак відноситься. Структуру Пірса часто подають у вигляді трикутника між трьома елементами. За ним для аналізу візуальних образів, не таким важливим є запитання про значення символу-знака, як вагомою $є$ різниця між значенням, що закладалось, і тим, як це сприймається інтерпретатором тобто спостерігачем [8].

Сучасні вчені вивчають знаки не окремо, а як частину «знакових систем», як групу ознак, які працюють разом, щоб створити сенс i 70 
будувати i підтримувати реальність. Концепція «код» $\epsilon$ фундаментальним поняттям в семіотиці. Соссюр, для прикладу, підкреслив, що знаки не мають сенсу у відриві від культури, а тільки тоді, коли вони інтерпретуються один щодо одного. Отже, код $є$ комплексом ознак, що циркулюють в певному суспільстві [9, с. 255].

Російсько-американський лінгвіст Р. Якобсон також підкреслив, що виробництво та інтерпретація знаків залежить від існування кодів або конвенцій для спілкування. Сенс знака залежить від коду, в якому він перебуває [10, с. 32]. А коди забезпечують рамки, в яких є ознаки сенсу. Інтерпретація тексту або зображення, а в нашому випадку графічної, візуальної комунікації, семіотично включає та пов'язує іiї 3 відповідними кодами.

Сьогодні графічні зображення дуже швидко проходять крізь цифровий потік соціальних мереж. «Графічна мова часто універсальна $\mathrm{i}$ легше долає кордони лінгвістичного розуміння. Найяскравішим прикладом є смайлики, які легко прижилися у глобальній мережі та повсякденній цифровій комунікації. Їх досліджують як візуальносмислові конструкції» [11]. Візуальна комунікація крізь цифрові мережі посилює глобалізаційні процеси. Стираються попередні значення знаків, створюються новіші, що стають універсальними для сьогодення.

За 20 років свого електронного існування ми вже можемо говорити про їx розвиток у бік їx графічного ускладнення, додавання різноманітності в емоційному діапазоні та колористичних рішеннях. Якщо в архаїчні часи, специфіка передачі матеріалу, потреба швидко зафіксувати важливі події, часто зумовлювала спрощення зображення, то на сьогодні технічні досягнення $\mathrm{i}$ специфіка середовища навпаки дозволяє їх ускладнювати. Нікого вже не здивувати анімованим зображенням, формат gif $\epsilon$ одним 3 найпоширенішим на любий інформаційних платформах.

\section{Література:}

1. Дядюх-Богатько Н.Й. Мистецтво декорування зброї на Гуцульщині у XVIII-XIX ст. : монографія. Львів : Вид-во Львівської Політехніки, 2018. 224 с.

2. Никорак О. I. Українська народна тканина XIX - XX ст.: автореф. канд. мист. / НАН Укр. Ін-т народознавства. Львів, 2006, 36 с.

3. Платов А.В. Руны славян и глаголица. Москва : Вече, 2010. 368 с.

4. Левус П.М. К истории копья из Ковеля. Российская археология. 2008. C. 121. URL : http://naukarus.com/k-istorii-kopya-iz-kovelya (дата звернення 21.11.2020). 
5. URL: https://mobile.twitter.com/RomArchable/status/13280099 85322835968? fbclid=IwAR11378TNWaviKOyO1 mvvdSUfHrLyaBRgKj2miJaRdI_6wOtSOE3q272y0 (дата звернення 21.11.2020)

6. Потебня О. Естетика i поетика слова [Збірник] / Упоряд. І. В. Іваньо, А. І. Колодної ; Пер. А. Колодної. Київ : Мистецтво, 1985. $302 \mathrm{c}$.

7. Соссюр Ф. Курс общей лингвистики / Перев. франц. А. М. Сухотина. М. : Логос, 1999.

8. Пирс Ч. Избранные философские произведения. М.: Логос, 2000. $412 \mathrm{c}$.

9. Дядюх-Богатько Н.Й. Комунікативний дизайн: крізь призму семантики. Поліграфічні, мультимедійні та WEB-технологї̈ / Матеріали III міжнар. наук.-техн. конф. Львів : УАД, 2018. С. 255-258.

10. D`Alleva, Anne. Methods \& Theories of Art History. London: Laurence King Publishing Ltd, 2005. 186 p.

11. Ковальчук, Н.П. Смайлики як візуально-смислові конструкції культури віртуального спілкування. Наукові записки / Нац. ун-т Острозька академія; відп. ред.: І.Д. Пасічник. Острог, 2011. Вип. 21. C. 50-57.

DOI https://doi.org/10.30525/978-9934-26-004-9-86

\title{
ПІДГОТОВКА МАЙБУТНІХ ХУДОЖНИКІВ-МАГІСТРІВ ДО ЗАСТОСУВАННЯ ТЕХНІК МОНУМЕНТАЛЬНО-ДЕКОРАТИВНОГО МИСТЕЦТВА
}

\author{
Завгородній Р. В. \\ аспірант кафедри теорії та історії мистецтвва \\ Київської державної академії декоративно-прикладного мистеитва \\ і дизайну імені Михайла Бойчука \\ м. Київ, Украӥна
}

Соціально-економічні зміни, що відбуваються в сучасному суспільстві, вимагають кардинального перегляду освітнього процесу в мистецьких ВНЗ, виявлення виникаючих суперечностей, пошуку шляхів їх подолання, розробки нових концептуальних підходів до проектування змісту мистецької освіти, розроблення освітніх програм і навчальних планів, які сприятимуть підвищенню ефективної фахової підготовки майбутнього художника монументально-декоративного мистецтва. 